\title{
PREFERENSI KONSUMEN GULA KELAPA DI PASAR GODEAN, KABUPATEN SLEMAN, PROVINSI DAERAH ISTIMEWA YOGYAKARTA
}

\author{
Azkia Nurhadi, Agus Setiadi, Hery Setiyawan
}

Universitas Padjadjaran

\begin{abstract}
ABSTRAK
Tujuan dari penelitian ini adalah untuk mengetahui preferensi konsumen mengenai gula kelapa yang beredar di pasaran saat ini. Penelitian telah dilaksanakan pada bulan Desember 2017 di Pasar Godean, Sleman, Daerah Istimewa Yogyakarta. Metode yang digunakan dalam penelitian ini adalah survei. Pengumpulan data dilakukan dengan wawancara langsung konsumen gula kelapa yang ada di Pasar Godean dengan bantuan kuisioner yang telah disusun sebelumnya. Lokasi penelitian ditentukan dengan metode purposive. Responden dalam penelitian ini berjumlah 100 orang konsumen gula kelapa. Responden ditentukan dengan metode accidental sampling. Data yang diambil dalam penelitian ini adalah data primer dan data sekunder. Data primer diperoleh dari wawancara langsung kepada konsumen gula kelapa, sedangkan data sekunder diperoleh dari sumber pustaka yang berkaitan dengan penelitian ini. Data yang telah diperoleh dari wawancara kemudian dilakukan analisis conjoint. Metode pengolahan data dilakukan dengan menggunakan bantuan aplikasi komputer SPSS.Hasil dari penelitian ini yaitu karakteristik konsumen gula kelapa yang ada di Pasar Godean diketahui bahwa 94\% adalah perempuan dengan jumlah anggota keluarga antara 26 orang. Sebagian besar konsumen gula kelapa di Pasar Godan adalah golongan pendapatan menengah dengan jumlah konsumgi mayoritas antara 1->2,5 kg/bulan/rumah tangga. Prrferensi konsumen gula kelapa di Pasar Godean, Preferensi kombinasi atribut gula kelapa berdasarkan urutan kepentingan relatif yang paling diprioritaskan oleh konsumen berturut-turut dalam membeli gula kelapa adalah berwarna coklat kehitaman, berukuran sedang, dan berbentuk tempurung kelapa.
\end{abstract}

Kata Kunci: Gula Kelapa, Preferensi Konsumen, Pasar.

\begin{abstract}
The purpose of this research is to know consumer preferences about palm sugar circulating in the market today. The research was conducted in December 2017 in Godean Market, Sleman, Daerah Istimewa Yogyakarta. The method used in this research is survey. The data was collected by direct interviews of consumers of coconut sugar in the Godean Market use questionnaire. The location of research is determined by purposive method. Respondents in this research amounted to 100 consumers of palm sugar. Primary data was obtained from direct interviews to consumers of palm sugar, while secondary data was obtained from literature sources related to this research. The data obtained from the interview is then done conjoint analysis. Data processing method is done by using SPSS computer application. The results of this research are the characteristics of consumers of coconut sugar in Godean Market known that $94 \%$ are women with the number of family members between 2-6 people. Most of the consumers of palm sugar in Godan market are middle income group with the majority of consume between 1-> $2.5 \mathrm{~kg} /$ month / household. palm sugar consumers' preferences in Godean Market, the preference for the combination of palm sugar attributes based on the order of relative importance most prioritized by consumers in consecutively buying coconut sugar is blackish brown, medium size, and shaped coconut shell.
\end{abstract}

Keywords: Palm Sugar, Consumer Preference, Market 


\section{PENDAHULUAN}

Gula merupakan salah satu dari sembilan bahan pokok kebutuhan pangan yang sangat penting bagi kebutuhan kita sehari-hari, baik dalam rumah tangga maupun industri makanan dan minuman. Gula juga menjadi kebutuhan yang sangat penting bagi tubuh karena gula mengandung kalori yang sangat penting bagi kesehatan kita. Gula juga digunakan sebagai bahan pemanis utama yang digunakan oleh banyak industri makanan dan minuman.

Di Indonesia dikenal jenis gula yang dinilai unik yaitu gula merah. Dikalangan masyarakat Indonesia jenis gula ini juga dikenal dengan nama gula kelapa ataupun gula jawa. Gula kelapa adalah jenis gula yang dihasilkankan dari nira kelapa yang dipanaskan hingga mengental lalu dicetak dan didinginkan hingga mengeras (Pratama et al., 2015). Keberadaan gula kelapa sangat penting bagi masyarakat Indonesia karena fungsinya yang tidak dapat digantikan oleh jenis gula lain seperti industri kecap, enting-enting, nopya dan industri rumahan lainya. Pada saat ini bentuk gula kelapa yang berada di pasaran pada umumnya berbentuk tempurung kelapa dengan berbagai ukuran (Heri dan Lukman, 2007). Selain ukurannya yang berbeda-beda, gula merah yang beredar di pasaran juga mempunyai tingkat kecerahan warna yang berbeda-beda ada yang cenderung gelap ada juga yang cerah. Tingkat kecerahan warna gula merah yang beredar di pasaran bergantung pada banyak faktor seperti cemaran dan suhu pemasakan nira kelapa hingga menjadi gula kelapa.

Konsumen dalam mengkonsumsi gula kelapa tentunya memilih gula kelapa dengan ciri tertentu yang sesuai dengan kebutuhan dan keinginan dari konsumen itu sendiri. Atributatribut yang melekat pada produk gula kelapa sangat diperhatikan oleh konsumen dalam pembelian gula yang akan dikonsumsi. Informasi pasar yang akurat secara lengkap dan rinci mencakup preferensi konsumen untuk mengetahui apa yang diinginkan dan dibutuhkan konsumen

Preferensi konsumen adalah pilihan suka atau tidak suka oleh seseorang terhadap produk yang akan dikonsumsi dari berbagai pilihan produk yang ada (Kotler, 2000).
Preferensi konsumen dapat menggambarkan segala informasi yang berhubungan dengan kebutuhan dan keinginan konsumen. Hal ini sangat penting bagi produsen gula kelapa untuk dapat menghasilkan produk yang mampu memenuhi keinginan dan kebutuhan konsumen. Produk yang sesuai kebutuhan dan keinginan konsumen maka nilai penjualan produk akan semakin meningkat, dengan peningkatan jumlah penjualan produk maka tingkat pendapatan produsen gula kelapa juga akan meningkat.

Tujuan dari penelitian ini adalah:

1. Mengidentifikasi karakteristik konsumen gula kelapa yang ada di Pasar Godean Kabupaten Sleman, Provinsi Daerah Istimewa Yogyakarta.

2. Menganalisis preferensi konsumen terhadap gula kelapa di Kabupaten Sleman, Provinsi Daerah Istimewa Yogyakarta.

\section{METODE PENELITIAN}

Penelitian telah dilaksanakan pada bulan Desember 2017, berlokasi di Pasar Godean yang terletak di Kabupaten Sleman, Daerah Istimewa Yogyakarta.

Metode penelitian yang digunakan dalam penelitian ini adalah metode survey. Metode survey dipilih karena dengan metode ini dapat memperoleh gambaran yang objektif mengenai suatu populasi. Untuk penelitian dengan metode survei pada populasi yang sangat besar maka pengumpulan data dapat dilakukan sampling (Sumantri dan Muhidin, 2006)

Lokasi penelitian dilakukan di Pasar, Godean, Kecamatan Godean, Kabupaten Sleman, Provinsi Daerah Istimewa Yogyakarta. Lokasi penelitian ini ditentukan dengan metode Purposive. Purposive yaitu metode penentuan lokasi dengan cara menentukan lokasi yang memenuhi kriteria tertentu yang sesuai dengan tujuan penelitian (Sugiyono, 2008). Alasan pemilihan lokasi di Pasar Godean, Kecamatan Godean, Kabupaten Sleman, Provinsi Daerah Istimewa Yogyakarta karena sumber gula kelapa di pasar ini berasal dari beberapa daerah, letak pasar yang berada di pusat kecamatan diharapkan dapat mewakili daerah lainya.

Metode pengambilan data diperoleh dari wawancara langsung kepada para konsumen 
gula kelapa yang ada di Pasar Godean dengan bantuan kuisioner yang telah disusun. Sampel diambil dengan menggunakan metode accidental sampling berdasarkan faktor spontanitas, artinya siapa saja yang secara tidak sengaja bertemu dengan peneliti dan sesuai dengan karakteristik, maka orang tersebut dapat digunakan sebagai sampel (Sugiyono, 2008). Responden yang digunakan sebanyak 100 orang konsumen gula yang dikonsumsi untuk sendiri.

Metode Analisis Data. Dalam penelitian ini penulis menggunakan analisis konjoin. Analisis konjoin adalah analisis yang paling umum yang diterapkan terhadap riset pasar dan studi pengembangan poduk dengan tujuan memperoleh nilai kegunaan yang dapat mewakili kepentingan setiap aspek produk, juga memperoleh nilai kepentingan relatif sehingga dari nilai tersebut dapat ditarik kesimpulan tentang atribut apa yang paling dipertimbangkan konsumen dalam memilih sebuah produk. Langkah-langkah analisis konjoin sebagai berikut (Taroreh et al., 2015) :

\section{1) Penetapan Tujuan}

Tujuan umum dari dilakukannya penelitian ini adalah menilai preferensi konsumen gula kelapa di Pasar Godean. Adapun tujuan khusus dari penelitian ini adalah untuk mengetahui atribut yang melekat pada produk apakah yang paling penting dan kombinasi atribut seperti apakah yang paling disukai oleh konsumen.

\section{2) Desain Analisis Konjoin}

Metode konjoin yang digunakan adalah traditional conjoint sedangkan metode presentasi yang digunakan dalam penelitian ini adalah full-profile. Selanjutnya dibuat profil dengan bantuan aplikasi SPSS. Atribut dan level didesain secara orthogonal dan menghasilkan kombinasi plan card yang akan digunakan sebagai profil. Atribut dan level tersebut diolah dengan aplikasi SPSS dan menghasilkan stimuli (kartu profil) yang dijadikan sebagai kuesioner.

Tabel 1

Atribut dan Taraf Pada Gula Kelapa

\begin{tabular}{lll}
\hline \hline Atribut & Taraf & Keteranga \\
\hline Bentuk & 1 & Cetakan \\
& 2 & tempurung kelapa \\
Ukuran & 1 & Cetakan bambu \\
& 2 & Besar $(>10 \mathrm{~cm})$ \\
Warna & 1 & Sedang $(<10 \mathrm{~cm})$ \\
& 2 & Coklat tua \\
\hline
\end{tabular}

\section{Coklat muda}

3) Asumsi Analisis Konjoin

Konsumen harus memberikan nilai (skor) dari masing-masing profil yang ada dan dari data tersebut selanjutnya dapat ditentukan apa yang akan menjadi preferensi konsumen dilihat dari beberapa nilai dan utilitas yang muncul setelah dilakukan olah data menggunakan SPSS. Penilaian ini menggunakan skala Likert seperti berikut:

Table 2.

Skala Likert

\begin{tabular}{ll}
\hline Pernyataan & Skor \\
\hline Sangat setuju & 5 \\
Setuju & 4 \\
Netral & 3 \\
Tidak setuju & 2 \\
Sangat tidak setuju & 1 \\
\hline
\end{tabular}

Secara umum, model dasar analisis konjoin dapat direpresentasikan dengan mengikuti rumus berikut (Malhotra, 2004).

$$
U(X)=\sum_{i=1}^{m} \sum_{j=1}^{k_{i}} \alpha_{i j} x_{i j}
$$

Keterangan: $\mathrm{U}(\mathrm{X})=$ Utility total

$\alpha_{\mathrm{ij}} \quad=$ Part worth atau nilai kegunaan dari atribut ke-i (i, i=1,2,.. m) taraf ke-j (j, $\mathrm{j}=1,2, \ldots, \mathrm{ki}$ )

$\mathrm{k}_{\mathrm{i}} \quad=$ Jumlah taraf dari atribut ke-i

$\mathrm{m} \quad=$ Jumlah atribut

$\mathrm{x}_{\mathrm{ij}} \quad=$ Dummy variable atribut ke-i taraf ke-j. (bernilai 1 bila taraf yang berkaitan muncul dan 0 bila tidak)

\section{4) Estimasi Model Konjoin}

Data yang didapatkan merupakan data numerik yang selanjutnya diolah dengan bantuan aplikasi SPSS. Selanjutnya, angka korelasi Kendall tau dan Pearson R digunakan dalam menentukan kehandalan profil serta mengukur predictive accuracy.

\section{HASIL DAN PEMBAHASAN Gambaran Umum Lokasi Penelitian} Pasar Godean adalah salah satu pasar tradisional yang yang berlokasi di jalan Godean Km. 9, Sidoagung, Godean, Sleman, Yogyakarta. Pasar Godean buka dari pukul 05.00 WIB hingga pukul 17.00 WIB. Pasar tradisional ini masih menganut sistem pasaran menurut kalender hai Jawa, maka hari pasaran 
paling ramai kunjungan konsumen di Pasar Godean yaitu pada saat hari Pon pada hari penanggalan jawa. Pasar Godean menempati lahan yang memiliki luas area seluas $9.000 \mathrm{~m}^{2}$ dengan jumlah pedagang yang mencapai 1.721 orang. Pasar ini menjual berbagai kebutuhan masyarakat seperti sembako, sayuran, buahbuahan, perkakas rumah tangga, jajan pasar, lauk pauk, minuman tradisional (aneka jamu), rempah-rempah (bumbu masak), aneka macam kardus dan plastik, kerajinan/gerabah dan aneka kebutuhan masyarakat lainya. Fasilitas publik yang ada di pasar ini meliputi area untuk parkir mobil \& motor untuk pedagang dan pengunjung, kamar mandi umum, warung makan, dan kantor sekretariat pasar.

\section{Gula Kelapa}

Gula Kelapa atau sering dikenal dengan istilah gula jawa atau gula merah adalah gula yang biasanya memiliki wujud padat dengan warna yang coklat kekuningan hingga coklat tua. Gula kelapa dihasilkan dari nira kelapa yang dipanaskan hingga mengental lalu dicetak dan didinginkan (Pratama et al., 2015). Gula kelapa memiliki rasa, bentuk dan aroma yang khas dan berbeda dari gula jenis lain sehingga penggunaannya tidak dapat digantikan oleh jenis gula yang lain. Selain memiliki fungsi sebagai pemberi rasa manis pada olahan makanan gula kelapa juga berfungsi untuk memberikan kesan warna coklat yang menarik pada makanan.

Gula kelapa yang ada di pasa godean memiliki dua macam bentuk, bentuk cetakan tempurung kelapa dan bentuk cetakan bambu. Hal ini sesuai dengan pendapat Heri dan Lukman (2007) gula kelapa yang ada di pasaran biasanya bentuk setengah elips yang dicetak menggunakan tempurung kelapa, ada pula yang berbentuk silindris yang dicetak menggunakan cetakann dari potonga batang bambu. Gua kelapa yang ada di Pasar Godean berasal dari Kabupaten Kulon Progo dan wilayah Kabupaten Sleman sendiri. Warna gula kelapa yang ada di Pasar Godean juga sangat beragam dari warna yang kuning cerah hingga coklat kehitaman serta ukuranta dari yang kecil dengan diameter $5 \mathrm{~cm}$ hingga yang besar dengan diameter mencapai $15 \mathrm{~cm}$.

\section{Hasil Uji Validitas dan Reliabilitas Kuesioner}

Kuesioner penelitian yang telah diisi oleh para responden sebelum dilakukan uji analisis lain diuji kesahihan dan kekonsistenannya dengan menggunakan uji validitas dan reliabilitas. Uji validitas dilakukan pada taraf tingkat kepercayaan 90\% $(\alpha=0,1)$. Kevalidan kuesioner dilihat dengan cara membandingkan antara r-hitung dengan $r-$ tabel. Nilai r-tabel yang dipakai adalah 0,197 pada taraf signifikan $(\alpha=0,1)$. Sugiyono (2015) menyatakan bahwa pertanyaan dalam kuisioner dinyatakan valid apabila nilai $r$ hitung yang merupakan nilai dari Corrected Item-Total Correlation lebih besar daripada $r$ tabel ( $r$ hitung $>r$ tabel). Hasil pengujian validitas kuesioner menunjukkan bahwa $r$ hitung dari tiap butir pertanyaan memiliki nilai yang lebih besar daripada r-tabel. Hal tersebut menunjukkan bahwa pertanyaan-pertanyaan yang ada dalam kuesioner dinyatakan valid.

Pengujian validitas dan reliabilitas tiap butir kuesioner penelitian ini dilakukan dengan bantuan aplikasi SPSS 23. Setelah kuesioner dinyatakan valid maka selanjutnya dilakukan uji reliabilitas. Metode yang digunakan untuk menguji reliabilitas kuesioner dalam penelitian ini adalah dengan teknik Cronbach's alpha. Gozali (2016) menyatakan bahwa nilai Cronbach's alpha tersebut harus lebih besar dari 0,60 supaya kuisioner dapat dikatakan reliabel. Berdasarkan hasil pengujian dengan teknik tersebut didapat nilai alpha sebesar 0,736 . Nilai ini lebih besar dari 0,60 yang artinya bahwa pertanyaan pada kuesioner dinyatakan reliabel.

\section{Karakteristik Konsumen Gula Kelapa}

Responden dalam penelitian ini yaitu konsumen gula kelapa di Pasar Godean dengan jumlah 100 orang yang ditentukan menggunakan teknik Accidental Sampling. Menurut Sugiyono (2008) teknik Accidental Sampling artinya siapa saja yang secara tidak sengaja bertemu dengan peneliti dan sesuai dengan karakteristik, maka orang tersebut dapat digunakan sebagai sampel. Dalam penelitian ini karakteristik yang dipakai yaitu konsumen gula kelap yang ada di Pasar Godean yang membeli gula kelapa untuk dikonsumsi sendiri.

\section{Jenis Kelamin \\ Karakteristik dari konsumen gula kelapa yang ada di Pasar Godean terdiri dari 94}


konsumen berjenis kelamin perempuan dan 6 konsumen berjenis kelamin laki-laki. Sebagian besar dari konsumen gula kelapa yang ada di Pasar Godean adalah perempuan yang mencapai tingkat presentasi sebesar 94\%. Konsumen gula kelapa yang ada di Pasar Godean sebagian besar adalah perempuan dapat terjadi karena pada umumnya perempuan adalah pihak yang paling berperan dalam membeli segala bahan kebutuhan pokok rumah tangga sehari- hari. Hal ini sesuai dengan pendapat Eliza et al. (2011) yang menyatakan bahwa pemenuhan kebutuhan pokok dalam rumah tangga dilakukan oleh perempuan sehingga dalam pembelanjaan kebutuhan pokok sebagian besar dilakukan oleh perempuan. Said (2007) menambahkan, bahwa gula kelapa adalah merupakan salah satu kebutuhan pokok rumah tangga yang termasuk dalam golongan sembako (sembilan bahan pokok).

\section{Usia}

Karakteristik usia dari konsumen gula kelapa terbanyak di Pasar Godean berdasarkan kelompok usianya yaitu terdiri dari $36 \%$ adalah konsumen dengan usia antara 46-55 tahun. Konsumen gula kelapa di Pasar Godean diawali dari usia rentang 26 tahun lalu naik dan turun lagi di usia 65 tahu. Peresebaran konsumen terjadi pada rentang usia antara 26 65 tahun ini dapat terjadi karena gula kelapa merupakan kebutuhan pokok yang sifatnya merupakan kebutuhan rumah tangga yang tergolong kedalam semilan bahan pokok (sembako) sehingga masyarakat yang sudah berumah tanggalah akan membeli gula kelapa. Said (2007) menambahkan, bahwa gula kelapa adalah merupakan salah satu kebutuhan pokok rumah tangga yang termasuk dalam golongan sembako (sembilan bahan pokok). Rentang usia ini adalah rentang usian yang ideal dimana seseorang berrumah tanga bersama dengan pasanganya. Kelompok usia antara 2170 adalah usia dimana umumnya seseorang sudah menikah dan juga masih hidup bersama dengan pasanganya dalam suatu rumah tangga bersama keluarganya dalam serumah.

\section{Jumlah Anggota Keluarga}

Sebagian besar jumlah anggota keluarga responden konsumen gula kelapa adalah keluarga dengan jumlah anggota keluarha terdiri 5 orang, dengan persentase sebesar
$37 \%$. Jumlah anggota keluarga ini dinilai wajar untuk ukuran sebuah keluarga yang terdiri dari ayah, ibu dan anak. Banyknya anggota ini mempengaruhi jumlah konsumsi gula kelapa. Banyak faktor yang mempengaruhi besarnya jumlah konsumsi rumah tangga salah satunya adalah jumlah anggota keluarga. Hal ini sesuai dengan pedapat (Prishardoyo et al., 2005). Yang menyatakan bahwa salah satu faktor yang mempengaruhi jumlah konsumsi rumah tangga adalah jumlah anggota keluarga dan komposisis keluargarumah tangga itu sendiri.

\section{Pendapatan Responden}

Pendapatan dari konsumen gula kelapa di Pasar Godean sebagian besar adalah masyarakat dengan kelas pendapatan menengah, secara terperinci terdiri dari $6 \%$ kelas menengah ke bawah dengan tingkat pendapatan keluarga kurang dari Rp $2.500 .000,00,82 \%$ kelas menengah dengan tingkat pendapatan antara Rp 2.600.000,00 Rp 6.000.000,00 dan 12\% kelas menengah ke atas dengan tingkat pendapatan lebih dari Rp 6.000.000,00. Hal ini sesuai dengan data BPPK Kementrian Keuangan (2015) di Indonesia yang termasuk kelas menengah adalah seseorang yang memiliki pendapatan antara Rp 2.600.000,00 - Rp 6.000.000,00, kurang dari Rp 2.500.000,00 merupakan kelas menengah ke bawah, dan lebih dari Rp 6.000.000,00 merupakan kelas menengah ke atas. Widjajanta dan Widyaningsih (2007) menyatakan bahwa Faktor terbesar yang mempengaruhi tingkat konsumsi rumah tangga yaitu pendapatan rumah tangga itu sendiri, ketika pendapatan mengalami kenaikan maka rumah tangga akan cenderung untuk semakin meningkatkan jumlah konsumsinya rumah tangganya.

\section{Frekuensi Konsumsi gula kelapa}

Responden konsumen gula kelapa lebih banyak mengkonsumsi gula kelapa sebayak 1 $\mathrm{kg}$ dalam periode satu bulan dengan presentase sebesar $27 \%$. Hal ini besedikit berbeda dengan pendapat Said (2007) yang menyatakan jumlah konsumsi gula kelapa sekitar 19 $\mathrm{kg} /$ keluarga/tahun. Namun tidak sedikit pula ruamh tangga yang mengkonsumsi gula kelapa dengan jumlah lebih dari $2,5 \mathrm{~kg}$. Hal ini dapat terjadi karena penelitian dilakukan di wilayah Yogyakarta yang masyarakatnya suka citarasa 
manis sehingga konsumsi gula kelapa masyarakat sekitar lebih besar. Nugroho et. al. (2012) menyatakan bahwa Dari segi makanan khas, masyarakat asli Yogyakarta lebih suka dengan makanan yang berasa manis dan tidak terlalu pedas.

\section{Analisis Proses Keputusan Pembelian}

Alasan Pembelian. Proses keputusan

pembelian diawali dengan pengenalan

kebutuhan. Kebutuhan timbul akibat rangsangan yang dirasakan konsumen. Pada tahap ini konsumen mencoba mengenal produk yang mereka butuhkan sesuai dengan keinginannya dan apa alasan yang mendorong mereka untuk mengkonsumsi suatu produk. Analisa tahap pengenalan kebutuhan dalam proses keputusan pembelian produk gula kelapa dilakukan dengan mengidentifikasi alasan konsumen dalam membeli produk gula kepala.

Alasan terbanyak responden membeli gula kelapa karena faktor rasa dengan presentase jumlah responden yang menjawab sebesar $77 \%$. Konsumen membeli gula kelapa karena gula kelapa memiiki rasa yang unik dan khas yang dapat membedakanya dengan gula jenis lainya. Hal ini sesuai dengan pendapat Pratama et al. (2015) yang menyayakan gula kelapa memiliki cita rasa yang khas sehingga penggunaannya tidak dapat digantikan oleh jenis gula yang lain. Alasan/motivasi konsumen selanjutnya adalah karena kebiasaan dengan presentase jumlah responden yang menjawab sebesar $22 \%$. Konsumen merasa terbiasa mengkonsumsi gula kelapa untuk kebutuhan tertentu yang posisinya tidak dapat digantikan oleh gula jenis lainya. Hal ini membuktikan bahwa pengaruh kebiasaan/ budaya berpengaruh sangat besar dalam penentuan keputusan pembelian.

Faktor lain yang menjadi alasan dalam konsumsi gula kelapa adalah faktor manfaat kesehatan dengan presentase jumlah responden yang menjawab sebesar $1 \%$. Segelintir konsumen merasa bahwa mengkonsumsi gua kelapa untuk kebutuhan tertentu memilki dampak kesehatan yang baik bagi tubuh dibandingkan dengan mengkonsumsi gula jenis lainya. Menurut Yanto et al. (2015) menambahkan gula kelapa memiliki indek glikemik tergolong rendah (35\%) jika dibandingkan dengan gula tebu (75\%), sedangkan batas kadar glikemik gula yang baik untuk kesehatan adalah $40 \%$.

Tingkat Kepentingan. Golongan tingkat kepentingan dalam mengkonsumsi gula kelapa bibagi menjadi dua. Sebanyak $62 \%$ responden menyatakan sanagat penting dan 39\% responden menyatakan penting. Tingkat kepentingan sangat penting dan penting saja yang dipilih karena gula kelapa keberadaanya untuk dikonsumsi sangatlah fital terutama bagi masyarakat jogja yang terkenal akan khas citarasa masakan yang manis. Citarasa masakan yang manis ini berasal dari gula kelapa yang digunakan untuk pemanisnya. Posisi gula kelapa untuk olahan tertentu tidak dapat digantikan dengan gula jenis lainya karena apabila digantikan dengan gula jenis lain makan tidak akan menghasilkan aroma serta rasa khas gula kelapa sehingga masyarakat menilai masakan menjadi kurang enak. Hal ini sesuai dengan pendapat Mashud dan Matana (2014) yang menyatakan bahwa gula kelapa merupakan hasil pengolahan nira kelapa dengan cita rasa yang khas sehingga penggunaannya tidak dapat digantikan oleh jenis gula yang lain untuk beberapa jenis makanan.

Tingkat Tetap Membeli. Seluruh konsumen gula kelapa di Pasar Godean yang dijadikan responden menyatakan bahwa akan tetap membeli produk gula kelapa meskipun harganya naik. Perilaku konsumen ini dapat terjadi karena fungsi dalam beberapa keperluan posis gula kelapa yang tidak dapat tergantikan oleh gula jenis lain. Hal ini sesuai dengan pendapat Pratama et al. (2015) yang menyayakan gula kelapa memiliki cita rasa yang khas sehingga penggunaannya tidak dapat digantikan oleh jenis gula yang lain. Kenaikan harga yang masih dapat ditolelir oleh konsumen gula kelapa tentunya kenaikan harga yang masih wajar untuk sebuah bahan kebutuhan pokok rumah tangga. Apabila kenaikan harga sudah melebihi ambang wajar makan konsumen gula kelapa juga akan memikirkan kemungkinan lain untuk menggantikan konsumsi gula kelapa.

\section{Evaluasi Pasca Pembelian. Sebanyak}

$60 \%$ dari konsumen gula kelapa merasa sangat puas dengan gula kelapa yang biasa dikonsumsi dan sisanya menyataka puas dengan gula kelapa yang biasa dikonsumsi dengan presentase sebanyak $40 \%$ konsumen. Konsumen merasa sangat puas dan puas 
karena menilai produk gula kelapa yang dijual oleh para pedagang gula kelapa yang ada di Pasar Godean sudah memenuhi kriteria produk yang mereka inginkan sehingga para konsumen merasa sangat puas atau puas. Hal ini sesuai dengan pendaat Irawan (2009) yang menyatakan konsumen meresa puas jika produk yang dikonsumsinya memberikan manfaat seperti apa yang diharapkan atau bahkan lebih. Keluhan juga pernah dirasakan oleh para konsumen terhadap gula kelapa yang ditawarkan oleh para pedagang. Keluhan para konsumen diantaranya yaitu gula yang sedikit terasa asin, gula sedikit kotor, gula lembek dan gula kelapa terdapat campuran gula pasir dalam pembuatanya. Soetanto (2000) menyatakan bahwa gula kelapa yang baik adalah gula kelapa yang bersih dari cemaran dan kadar air yang terjaga. Setandar Nasional Indonesia (1995) mengenai gula palma menambahkan untuk gula palma padat kanduangan air maksimal $10 \%$.

\section{Uji Korelasi}

\section{Hubungan Usia Responden Dengan} Jumlah Konsumsi Gula Kelapa. Analilis uji korelasi menggunakan uji korelasi spearman menghasilkan nilai koefisien korelasinya 0,045 yang artinya korelasi diantara keduanya sangat lemah. Hal ini sesuai pendapat Nisfiannoor (2012) yang menyatakan bahwa jika nilai koefisien korelasi $0-0,25$ artinya korelasi diantara keduanya sangat lemah. Tanda negatif pada koefisien korelasi menunjukkan bahwa arah korelasi belawanan arah, yang artinya semakin bertambahnya usia maka semakin rendah jumlah konsumsinya. Nilai sig.(2-tailed) adalah 0,660 yang besarnya masih lebih besar daripada batas kritis $\alpha=$ 0,05 , berarti tidak terdapat hubungan yang signifikan antara kedua variabel $(0,660<0,05)$. Hal ini didukung oleh pendapat Barliana dan Cahyani (2012) yang menyatakan untuk melihat signifikasi hubungan antara variabel dapat dianalisis dengan melihat nilai Sig (twotailed), jika nilai Sig (two-tailed) $<0.05$ maka hubungan kedua variabel signifikan dan jika nilai Sig (two-tailed) > 0.05 maka hubungan kedua variabel tidak signifikan.

\section{Hubungan Jumlah Keluarga Dengan} Jumlah Konsumsi Gula Kelapa. Analilis uji korelasi menggunakan uji korelasi spearman menghasilkan nilai koefisien korelasinya 0,411 yang artinya korelasi diantara keduanya cukup.
Hal ini sesuai pendapat Nisfiannoor (2012) yang menyatakan bahwa jika nilai koefisien korelasi 0,26-0,50 artinya korelasi diantara keduanya cukup. Tanda positif pada koefisien korelasi menunjukkan bahwa arah korelasi searah, yang artinya semakin bertambahnya jumlah anggota keluarga maka semakin banyak jumlah konsumsinya. Nilai sig.(2tailed) adalah 0,000 yang besarnya masih lebih kecil daripada batas kritis $\alpha=0,05$, berarti terdapat hubungan yang signifikan antara kedua variabel $(0,000<0,05)$. Hal ini didukung oleh pendapat Barliana dan Cahyani (2012) yang menyatakan untuk melihat signifikasi hubungan antara variabel dapat dianalisis dengan melihat nilai Sig (two-tailed), jika nilai Sig (two-tailed) $<0.05$ maka hubungan kedua variabel signifikan dan jika nilai Sig (twotailed) $>0.05$ maka hubungan kedua variabel tidak signifikan.

\section{Hubungan Tingkat Pendidikan}

Dengan Jumlah Konsumsi Gula Kelapa.

Analilis uji korelasi menggunakan uji korelasi spearman menghasilkan dan nilai koefisien korelasinya 0,010 yang artinya korelasi diantara keduanya sangat lemah. Hal ini sesuai pendapat Nisfiannoor (2012) yang menyatakan bahwa jika nilai koefisien korelasi $0-0,25$ artinya korelasi diantara keduanya sangat lemah. Tanda positif pada koefisien korelasi menunjukkan bahwa arah korelasi searah, yang artinya semakin tinggi tingkat pendidikan maka semakin tinggi jumlah konsumsinya. Nilai sig.(2-tailed) adalah 0,920 yang besarnya masih lebih besar daripada batas kritis $\alpha=$ 0,05 , berarti tidak terdapat hubungan yang signifikan antara kedua variabel $(0,920<0,05)$. Hal ini didukung oleh pendapat Barliana dan Cahyani (2012) yang menyatakan untuk melihat signifikasi hubungan antara variabel dapat dianalisis dengan melihat nilai Sig (twotailed), jika nilai Sig (two-tailed) $<0.05$ maka hubungan kedua variabel signifikan dan jika nilai Sig (two-tailed) > 0.05 maka hubungan kedua variabel tidak signifikan.

\section{Hubungan Tingkat Pendapatan}

\section{Dengan Jumlah Konsumsi Gula Kelapa.}

Analilis uji korelasi menggunakan uji korelasi spearman menghasilkan nilai koefisien korelasinya 0,044 yang artinya korelasi diantara keduanya sangat lemah. Hal ini sesuai pendapat Nisfiannoor (2012) yang menyatakan bahwa jika nilai koefisien korelasi $0-0,25$ artinya korelasi diantara keduanya sangat 
lemah. Tanda positif pada koefisien korelasi menunjukkan bahwa arah korelasi belawanan arah, yang artinya semakin bertambahnya jumlah pendapatan maka semakin rendah jumlah konsumsinya. Nilai sig.(2-tailed) adalah 0,666 yang besarnya masih lebih besar daripada batas kritis $\alpha=0,05$, berarti tidak terdapat hubungan yang signifikan antara kedua variabel $(0,666<0,05)$. Hal ini didukung oleh pendapat Barliana dan Cahyani (2012) yang menyatakan untuk melihat signifikasi hubungan antara variabel dapat dianalisis dengan melihat nilai Sig (two-tailed), jika nilai Sig (two-tailed) $<0.05$ maka hubungan kedua variabel signifikan dan jika nilai Sig (twotailed) $>0.05$ maka hubungan kedua variabel tidak signifikan.

\section{Preferensi Konsumen Gula Kelapa}

Preferensi konsumen terhadap produk gula kelapa dapat diketahui dari atribut yang dipilih oleh para konsumen gula kelapa. Hal ini sesuai dengan pendapat Preferensi konsumen terhadap suatu produk dapat diukur dengan mengetahui aspek dari kualitas produk tersebut. Atribut yang digunakan sebagai objek pilihan para konsuen gula kelapa dalam penelitian ini adalah bentuk, ukuran dan warna. Hasil analisis Konjoin mengenai preferensi konsumen gula dapat dilihat pada tabel 4.

Tabel 4.

Hasil Analisis Konjoin preferensi konsumen gula kelapa di Pasar Godean.

\begin{tabular}{llll}
\hline \hline Atribut & & $\begin{array}{l}\text { Utility } \\
\text { Estimate }\end{array}$ & $\begin{array}{l}\text { Std, } \\
\text { Error }\end{array}$ \\
\hline Bentuk & Tempurung & 0.070 & 0.135 \\
& Bambu & -0.070 & 0.135 \\
Ukuran & Kecil & 0.030 & 0.135 \\
& Besar & -0.030 & 0.135 \\
Warna & Hitam & 0.042 & 0.135 \\
& Kuning & -0.042 & 0.135 \\
(Constant) & & 2.765 & 0.135 \\
\hline
\end{tabular}

Berdasarkan Tabel 4. diketahui bahwa atribut gula kelapa dengan bentuk cetakan tempurung kelapa bernilai utilitas positif dengan nilai utilitasnya 0,070 yang artinya konsumen lebih produk gula kelapa dengan bentuk cetakan tempurung kelapa dibanding dengan produk gula kelapa dengan bentuk cetakan bambu. Atribut gula kelapa dengan ukuran kecil juga mempunyai nilai utilitas positif dengan nilai utilitasnya 0,030 yang artinya konsumen lebih menyukai gula kelapa dengan ukuran kecil dibandingkan dengan gula kelapa dengan ukuran yang besar.

Atribut gula kelapa dengan warna hitam juga mempunyai nilai utilitas positif dengan nilai utilitasnya 0,042 yang artinya konsumen lebih menyukai gula kelapa dengan warna hitam dibandingkan dengan gula kelapa dengan warna kuning. Menurut Gozali (2016) nilai utility merupakan selisih antara nilai ratarata faktor tertentu dengan nilai constant, jika nilai utility positif maka responden suka dengan stimulasi tersebut dan jika nilai utility negative artinya responden kurang suka terhadap stimulasi tersebut. Hasil output lengkap mengenai analisis Konjoin dapat dilihat pada Lampiran X. Urutan kepentingan (importance value) terhadap atribut gula kelapa dapat dilihat pada Tabel 5.

Tabel 5.

Importance Value gula kelapa di Pasar Godean.

\begin{tabular}{ccc}
\hline \hline No. & Atribut & Persentase \\
\hline & & $-----------\%$------ \\
& & ----- \\
1. & Bentuk & 28.328 \\
2. & Ukuran & 35.636 \\
3. & Warna & 36.036 \\
\hline
\end{tabular}

Menurut Gozali (2016) nilai importance value adalah nilai yang paling mempengaruhi atribut yang paling disukai. Pada Tabel 21 terlihat atribut yang paling penting pertama adalah warna dari produk gula kelapa itu sendiri dengan nilai importance value sebesar $36.036 \%$, kedua adalah ukuran dari produk gula kelapa dengan nilai importance value $35.636 \%$, dan yang terakhir adalah bentuk dari produk gula dengan nilai importance value $28.328 \%$.

Atribut Warna Gula Kelapa. Atribut warna gula kelapa memiliki nilai importance value sebesar $36.036 \%$. Atribut warna gula berdasarkan tabel 12 memiliki nilai importance value yang paling tinggi diantara yang lainnya. Nilai importance value tertinggi artinya konsumen gula kelapa lebih mengutamakan atribut warna gula kelapa dibanding atribut lainnya. Warna gula kelapa dianggap penting oleh para konsumen karena fungsi gula kelapa dalam banyak olahan makanan dan minuman selain untuk pemberi rasa manis alami pada olahan makanan juga berperan sebagai pewarna yang dapat 
memberikan warna yang menarik pada makanan hasil olahan itu sendiri. Hal ini sesuai pendapat Zuliana et al. (2016) yang menyatakan bahwa Selain berfungsi sebagai pemanis, gula kelapa juga berfungsi sebagai pemberi warna coklat pada makanan olahan. Pemilian warna gula kelapa yang sesuai dengan tujuan penggunaanya akan berakibat pada warna hasil olahan makanan ataupun minuman yang menarik.

Pada atribut warna yang melekat pada gula kelapa konsumen lebih memilih gula kelapa yang berwarna coklat kehitam dibandingkan dengan gula kelapa yang berwarna kuning. Konsumen lebih memilih gula berwarna hitam karena gula berwarna coklat kehitaman akan memberikan warna coklat yang menarik untuk bebrapa macam olahan pangan. Dengan banyaknya kebutuhan olahan makanan yang membutuhkan warna kecoklatan dari gula kelapa maka akibatnya konsumen lebih memilih gla berwarna coklat kehitaman. Makanan dan minuman olahan yang membutuhkan warna dari gula yang berwarna coklat kehitaman supaya penampilanya menarik misalnya baceman, wajik, dodol dan juga dawet. Gula yang berwarna coklat kekuningan jika digunakan pada olahan makanan atau minuman ini maka hasil olahanya akan menjadi pucat dan tidak menarik.

Atribut Ukuran Gula Kelapa. Ukuran gula kelapa menjadi prioritas ke dua konsumen dalam memilih gula kelapa dibawah warna gula kelapa. Ukuran gula kelapa memiliki nilai importance value sebesar $35.636 \%$. Atribut ukuran dipandnag penting oleh konsumen karena ukuran suatu produk yang dibelinya untuk dikonsumsi biasanya akan disimpan terlebih dahulu sebagian tidak langsung dikonsumsi semuanya untuk kebutuhan yang mempunyai masa simpan cukup lama seperti gula. Jadi dalam membeli gula konsumen juga akan memikirkan ukuran yang sesuai untuk kemudahanya dalam menyimpan produk yang dibelinya supaya evisien tempat dan mudah dalam penggunaanya.

Pada atribut ukuran yang melekat pada gula kelapa konsumen gula kelapa yang ada di Pasar Godean lebih memilih gula kelapa dengan ukuran yang berukuran kecil dibandingkan dengan gula kelapa yang berukuran besar. Gula kelapa yang berukuran kecil lebih mudah dalam menyimpanya dibandingkan dengan gula kelapa yang berukuran besar. Gula kelapa yang berukuran kecil selain lebih mudah dalam penyimpannannya gula kelapa yang berukuran kecil juga lebih mudah dalam penggunannya karena sudah berukuran kecil sehingga tinggal digunakan atau kalau mau dibagi lagi juga lebih mudah dibandingkan gula kelapa dengan ukuran yang besar. Hal ini sesuai dengan pendapat Santoso (1993) yang menyatakan bahwa konsumen lebih menyukai gula kelapa yang berukuran cenderung kecil. Standar ukuran gula kelapa ekspor adalah $250 \mathrm{~g}$.

Atribut Bentuk Gula Kelapa. Bentuk gula kelapa menjadi prioritas ke tiga konsumen dalam memilih gula kelapa dibawah warna gula kelapa dan ukuran gula kelapa. Bentuk gula kelapa memiliki nilai importace value sebesar $28.328 \%$. Bentuk gula kelapa yang beredar di pasaran terdiri dari berbagai bentuk, bentuk ini berasal dari cetakan yang digunakan untuk mencetak gula kelapa itu sendiri. Hal ini sesuai dengan pendapat Heri dan Lukman (2007) yang menyatakan bahwa gula kelapa yang ada di pasaran biasanya bentuk setengah elips yang dicetak menggunakan tempurung kelapa, ada pula yang berbentuk silindris yang dicetak menggunakan potonga batang bamboo. Cetakan yang digunakan oleh para pengrajin gula kelapa umumnya dari tempurung kelapa dan juga dari bamboo. Cetakan ini digunakan karena keberadaanya dekat dengan mereka dan kemudahanya dalam mendapatkan cetakan terseut.

Atribut bentuk gula kelapa yang ada di pasar goden terdiri dari dua bentuk gula kelapa. Bentuk gula kelap berdasarkan pada cetakan yang digunakan oleh pengrajin gula yaitu bentuk tempurung kelapa dan bentuk bambu. Pada atribut bentuk konsumen gula kelapa yang ada di Pasar Godean lebih suka bentuk cetakan tempurung kelapa dibandingkan dengan cetakan bambu.

\section{SIMPULAN DAN SARAN}

Simpulan. Berdasarkan hasil penelitian dapat diketahui bahwa karakteristik konsumen gula kelapa yang ada di Pasar Godean diketahui bahwa $94 \%$ adalah perempuan dengan jumlah anggota keluarga antara 2-6 orang. Sebagian besar konsumen gula kelapa di Pasar Godan adalah golongan pendapatan 
menengah dengan jumlah konsumgi mayoritas antara $1->2,5 \mathrm{~kg} / \mathrm{bulan} / \mathrm{rumah}$ tangga.

Prferensi konsumen gula kelapa di Pasar Godean, Preferensi kombinasi atribut gula kelapa berdasarkan urutan kepentingan relatif yang paling diprioritaskan oleh konsumen berturut-turut dalam membeli gula kelapa adalah berwarna coklat kehitaman, berukuran sedang, dan berbentuk tempurung kelapa.

Saran. Sebaiknya pedagang harus lebih selektif dalam membeli gula kelapa untuk dijual kembali supaya sesuai dengan harapan konsumen, selain itu gula yang dipilih juga harus sesuai dengan kualitas dari gula yang dijual baik dan tidak mengecewakan konsumen. Selai selektif dalam membeli gula pedagang juga harus menjaga kualitas barang daganganya suppaya tidak terkena cemaran dari luar supaya tetap terjaga kualitas daganganya sesuai dengan standar mutu gula kelapa yang baik

\section{DAFTAR PUSTAKA}

Barliana, S. dan D. Cahyani. 2012. Arsitektur, Urbanitas, dan Pendidikan Budaya Berkota. Ogyakarta: deepublish.

Eliza, E. Sayamar dan C. Kaswita. 2011. Analisis faktor-faktor yang mempengaruhi konsumen dalam pengambilan keputusan pembelian buah di pasar arengka (pasar tradisional dan Giant Hypermarket (pasar modren) di Kecamatan Tampan Kota Pekanbaru. J. Agricultural Economics 2 (1): 15-34

Ghozali, I. 2016. Aplikasi Analisis Multivariat Dengan Program IMB SPSS 21.

Semarang: Badan Penerbit Universitas Diponegoro

Heri, M., M. Lukman. 2007. Pendampingan penerapan diversifikasi produk gula kelapa/merah kemasan kecil. J. Dedikasi 4: 73-81.

Irawan, D H. 2009. 10 Prinsip Kepuasan

Pelanggan. Jakarta: Elex Media Komputindo

Kotler, P. 2000. Manajemen Pemasaran (Terjemahan). Edisi Milenium. PT. Indeks. Jakarta.

Mashud, N. Dan Y. R. Matana. 2014. Produktivitas Nira Beberapa Aksesi Kelapa Genjah J. Palma 15 (2): 110 114
Maalhotra, NK. 2004. Marketing Research an Applied Orientation. United States: Pearson Education International.

Nisfiannoor, M. 2009. Pendekatan Statististika Modern Untuk Ilmu Sosial. Jakarta: Salemba Humanika

Nugroho, A. B., P. Lestari, I. Wiendijarti. 2012. Pola Komunikasi Antar Budaya Batak dan Jawa di Yogyakarta. J. Komunkasi 1 (5): 403-418

Pratama, F., W. H. Susanto dan I. Purwantiningrum 2015. Pembuatan gula kelapa dari nira terfermentasi alami. J. Pangan dan Agroindustri. 3 (4):.12721282

Said, ahmad. 2007. Pembuatan gula kelapa. Jakarta: Ganeca Exact

Santoso, B. 1993. Pembuatan Gula Kelapa. Kanisius. Yogyakarta.

Soetanto, Edy. 2000. Teknologi Tepat Guna Membuat Gula Kelapa Kristal. Yogyakarta: Kanisius

Somantri, A., S.A. Muhidin. 2006. Aplikasi Statistika Dalam Penelitian. Bandung: CV. Pustaka Setia.

Sugiyono. 2008. Statistika Untuk Penelitian. Bandung: Alfabeta

Standar Nasional Indonesia. 1995. Gula Palma. Badan Standar Nasional: SNI 01-3743-1995

Taroreh, O., R. J. Jorie, R. Wenas. 2015. Pengaruh persepsi konsumen dan kepercayaan terhadap penggunaan jasa asuransi pada asuransi Jasindo Manado. J. EMBA 3 (3): 312-321.

Yanto, T., Karseno dan M. M. D. Purnamasari. 2015. Pengaruh jenis dan konsentrasi gula terhadap karakteristik fisikokimia dan sensori jelly drink. J. Teknologi Hasil Pertanian. 8 (2): 123-129.

Zuliana, E. Widyastuti1, W. H. Susanto. 2016. Pembuatan gula semut kelapa (kajian ph gula kelapa dan konsentrasi natrium bikarbonat). J. Pangan dan Agroindustri 4 (1): 109-119. 
Vol. 3, No. 1, Juli 2018: 359-426

AGRICORE:Jurnal Agribisnis dan Sosial Ekonomi Pertanian 